\title{
Article \\ Responses of Runoff and Soil Loss to Rainfall Regimes and Soil Conservation Measures on Cultivated Slopes in a Hilly Region of Northern China
}

\author{
Haiyan Fang ${ }^{1,2}$
}

1 Key Laboratory of Water Cycle and Related Land Surface Processes, Institute of Geographic Sciences and Natural Resources Research, Chinese Academy of Sciences, Beijing 100101, China; fanghy@igsnrr.ac.cn; Tel.: +86-010-6488-3172

2 College of Resources and Environment, University of Chinese Academy of Sciences, Beijing 100049, China

Citation: Fang, H. Responses of Runoff and Soil Loss to Rainfall Regimes and Soil Conservation Measures on Cultivated Slopes in a Hilly Region of Northern China. Int. J. Environ. Res. Public Health 2021, 18, 2102. https://doi.org/10.3390/ ijerph18042102

Academic Editor: Daniela Varrica

Received: 20 January 2021

Accepted: 18 February 2021

Published: 21 February 2021

Publisher's Note: MDPI stays neutral with regard to jurisdictional claims in published maps and institutional affiliations.

Copyright: (C) 2021 by the author. Licensee MDPI, Basel, Switzerland. This article is an open access article distributed under the terms and conditions of the Creative Commons Attribution (CC BY) license (https:// creativecommons.org/licenses/by/ $4.0 /)$.

\begin{abstract}
Cultivated land plays an important role in water and soil loss in earthy/rocky mountainous regions in northern China, however, its response to soil conservation measures and rainfall characteristics are still not fully understood. In the present study, 85 erosive rainfall events in 2011-2019 were grouped into three types, and the responses of runoff and soil loss to soil conservation measures and rainfall regimes on five cultivated plots with different slopes in the upstream catchment of the Miyun Reservoir were evaluated. Results found that mean event runoff depths and soil loss rates on the five plots ranged from $0.03 \mathrm{~mm}$ to $7.05 \mathrm{~mm}$ and from $0.37 \mathrm{t} \mathrm{km}^{-2}$ to $300.51 \mathrm{t} \mathrm{km}^{-2}$ respectively, depending on rainfall regimes, soil conservation measures, and slope gradients. The high frequency (i.e., 72.94\%) rainfall regime $\mathrm{A}$ with a short rainfall duration (RD), low rainfall amount (P), and high mean rainfall intensity $\left(\mathrm{I}_{\mathrm{m}}\right)$ yielded a lower runoff depth and higher soil loss rate. Rainfall regime $B$ with a longer $R D$, and a higher $P$ and $I_{m}$, however, produced higher a runoff depth and lower soil loss rate. Terraced plots had the highest runoff and soil loss reduction efficiencies of over $96.03 \%$. Contour tillage had comparable sediment reduction efficiency to that of the terraced plots on gentle slopes (gradient less than $11.0 \%$ ), while its runoff reduction efficiency was less than $13.11 \%$. This study implies that in the Miyun Reservoir catchment and similar regions in the world, contour tillage should be promoted on gentle slopes, and the construction of terraced plots should be given ample consideration as they could greatly reduce water quantity and cause water shortages in downstream catchments.
\end{abstract}

Keywords: cultivated land; rainfall regime; soil conservation measure; reduction efficiency; northern China

\section{Introduction}

Soil erosion is an expansive environmental problem with significant ecological implications. It is associated with on-site land degradation, off-site sediment siltation in rivers, reservoirs, and lakes, and water resource use [1-3]. Thus, it directly and indirectly influences water, soil, and organism health as well as other earth surface processes [3].

It is widely recognized that land use affects soil loss. Among all the land use types, sloping cultivated land usually suffers higher soil loss and acts as an important sediment source area $[4,5]$. In the Ethiopian Plateau of Africa, the average soil loss rate (SLR) of sloping farmland is around $8000 \mathrm{t} \mathrm{km}^{-2} \mathrm{yr}^{-1}$, representing the land use type suffering from the highest soil loss in sub-Saharan Africa [6]. In China, sloping farmland covers an area of around 24.5 million ha, occupying approximately a fifth of the cultivated land, and annual soil loss from sloping farmland is approximately $1.5 \times 10^{9} \mathrm{t} \mathrm{yr}^{-1}$, contributing to around $30 \%$ of the total soil loss in China [7]. On the Loess Plateau, the SLR can be up to 9700$21,700 \mathrm{t} \mathrm{km}^{-2} \mathrm{yr}^{-1}$, and under conditions of extreme rainstorms even $6.94 \times 10^{3}-95.89 \times$ $10^{3} \mathrm{t} \mathrm{km}^{-2}$, which is dozens of times the rate of grass and forest lands [8]. In the Sichuan 
Basin of China, the SLR on sloping farmlands can also reach $3000-5000 \mathrm{t} \mathrm{km}^{-2} \mathrm{yr}^{-1}$, and soil loss from the cultivated land accounts for $60-80 \%$ of the total [9]. Therefore, soil and water resource protection and corresponding scientific research on sloping farmland are particularly important and necessary.

The Miyun Reservoir is an important source of drinking water for people in Beijing, $70 \%$ of which is provided by the Miyun Reservoir [10-13]. Therefore, the water quality and quantity of the Miyun Reservoir and its upstream catchment have attracted much attention by local government and research scholars. In recent years, many studies have been conducted in this region, mainly focusing on water pollution [14], water purification [15], nitrogen and phosphorus loss [16,17], and soil pollution [11,18]. In the process of soil erosion, the dissolved pollutants in runoff and/or those adsorbed onto the sediments can be routed out, resulting in downstream water pollution [19]. Therefore, soil erosion in the upper reaches of the reservoir has also attracted attention, and a large number of soil conservation measures have been implemented in the mountainous areas, including contour tillage, terraces, tree planting, and dams in gullies and/or rivers $[11,13,20]$.

In the last two decades, researches on soil erosion and its response to soil conservation measures have been done in this region. At the catchment scale, studies on the effect of land use change and soil conservation measures on runoff and sediment transport dynamics have been conducted [12,13,21-23]. At the slope scale, the characteristics of water and soil loss and their responses to soil conservation measures were also analyzed $[19,21,24,25]$. Nowadays, cultivated lands in the upstream catchment of the Miyun Reservoir still act as important sediment and pollution source areas, and contour tillage and terrace practices have been widely implemented in this region [12,13,21]. Intensive anthropogenic activities and lasting dry years have resulted in a dramatically reduced streamflow into the Miyun Reservoir $[23,26]$. Thus, comparisons of runoff and soil loss from cultivated lands in this region have important implications. However, evaluations of the responses of runoff and soil loss on cultivated lands to different rainfall characteristics and soil conservation measures are scarely done. Therefore, it is vitally important to cope with future extreme rainstorms through managing land use in the hilly regions around the capital city of China $[13,23]$.

Therefore, runoff and soil erosion data from 85 erosive rainfall events over five cultivated plots were used to explore the responses of runoff and soil loss to soil conservation measures and rainfall characteristics in the upstream catchment of the Miyun Reservoir, northern China. The specific aims were to (i) compare the differences in surface runoff and soil loss under different soil conservation measures, (ii) identify their responses to different types of rainfall events, and (iii) give suggestions to implement reasonable soil conservation measures in the study area.

\section{Materials and Methods}

\subsection{Study Site}

The study area is located in the Shixia catchment $\left(117^{\circ} 4^{\prime} 30^{\prime \prime} \mathrm{E}\right.$ and $\left.40^{\circ} 34^{\prime} 40^{\prime \prime} \mathrm{N}\right)$ (Figure 1), upstream of the Miyun Reservoir, some $90 \mathrm{~km}$ northeast of Beijing. The catchment lies in the Yanshan Mountains, and has a temperate territorial monsoon climate. Mean annual precipitation is $661.8 \mathrm{~mm}$, ranging from $300 \mathrm{~mm}$ to $700 \mathrm{~mm}, 70 \%$ of which falls from June to August. The annual evaporation is $1840 \mathrm{~mm}$.

The catchment has an area of $33 \mathrm{~km}^{2}$ with elevations of 130-390 m a.s.l. It exhibits an earth-rock hilly geomorphology. Around $20.6 \%$ of the catchment has a slope gradient od less than $8.7 \%, 50.2 \%$ of the slopes range from $8.7 \%$ to $26.8 \%$, and slopes larger than $36.4 \%$ only account for $16.2 \%$ of the total. The lithology is dominated by gneiss, scattered with granite and limestone. The soil cover consists of cinnamon soils, as per the Chinese soil classification system which was developed on alluvial and diluvial parent materials. The soils are around $30 \mathrm{~cm}$ in depth, and around a $10 \mathrm{~cm}$ horizon of weathered rock mixed with soil appears under the soil layer. The catchment is mostly covered by artificial Robinia 
pseudoacacia, Pinus tabulaeformis, and economic forest. The major crops are corn (Zea mays) and wheat (Triticum aestivum).

\subsection{Description of the Selected Runoff Plots}

There are 22 runoff plots in the catchment (Figure 1). The boundaries of each plot were made of bricks and cement to prevent runoff from leaving or entering the plot. The plots are bare, covered with different types of vegetation, or implemented with different soil conservation measures. Among the 22 runoff plots, only five plots were cultivated, consisting of one plot without soil conservation measures, one plot with $4 \mathrm{~m}$ wide terrace, and three plots with contour tillage. In order to specifically study the effects of the soil conservation measures and slope gradients on the runoff and soil loss from cultivated slopes, all these five plots were selected in the present study. Each plot was $50 \mathrm{~m}^{2}$ in area and $5 \mathrm{~m}$ in width. The slope gradients range from $6.1 \%$ to $29.6 \%$ with soil thicknesses of around $30 \mathrm{~cm}$. Detailed information of the plots was given in Table 1.

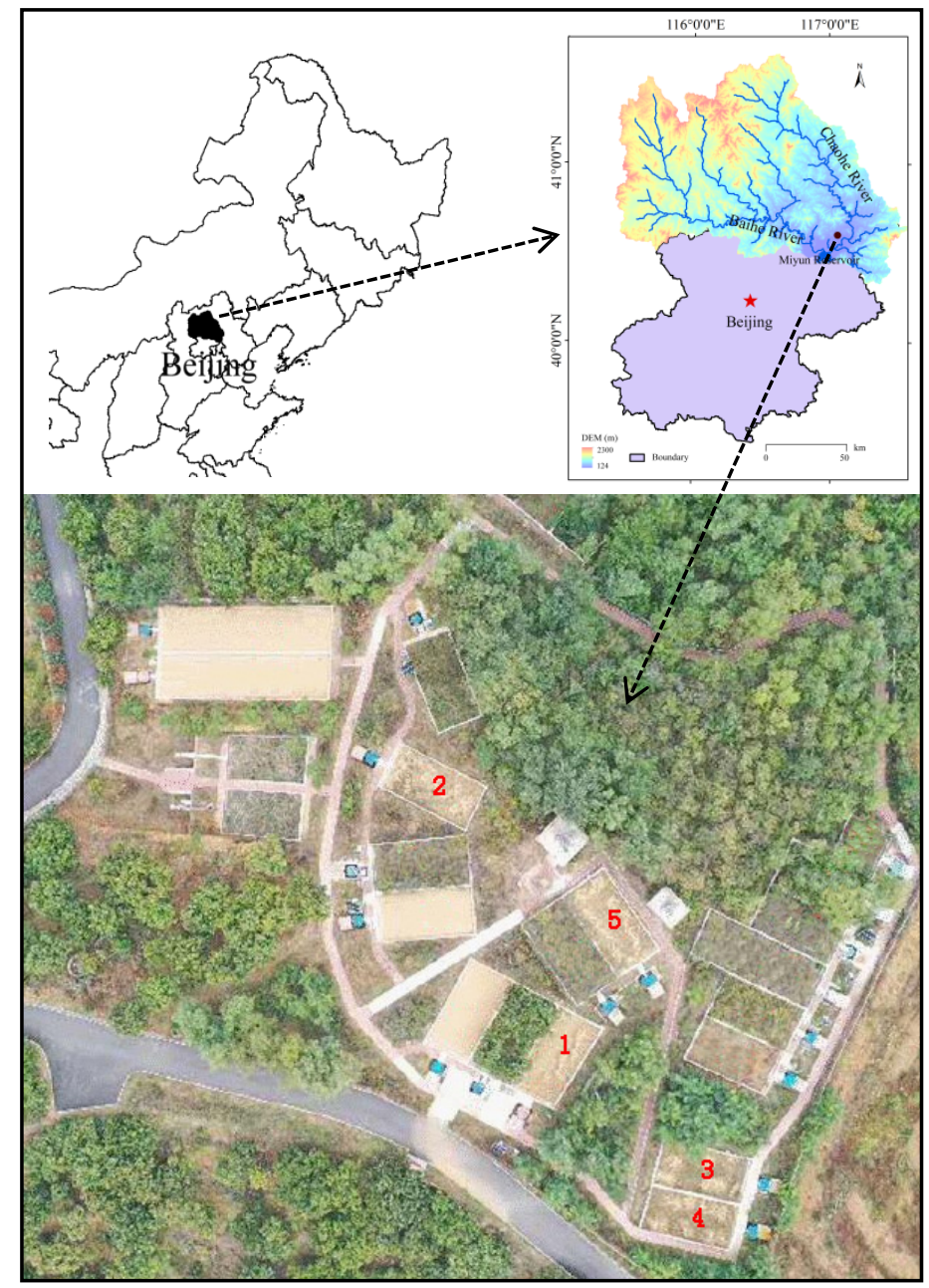

Figure 1. Location of the study area and the cultivated runoff plot selected. The red figures represent the plots in Table 1 (The bottom map showing the plots' distribution was edited from Xu [27]).

\subsection{Data Collection}

Surface runoff and soil loss were collected and measured after each rainfall event in 2011-2019. A nine-hole diversion bucket and a tank were used to collect the runoff mixed with sediment from the plots. The runoff amount was calculated and sampled with $1000 \mathrm{~mL}$ flasks after each rainfall. After settling for $24 \mathrm{~h}$, sediment was separated from the water, dried in an oven at a temperature of $105^{\circ} \mathrm{C}$, and subsequently weighted to determine the sediment concentration. The soil loss of each plot was calculated by multiplying the 
average sediment concentration and the runoff amount. The runoff depth $(\mathrm{H} ; \mathrm{mm})$ of the plot after each rainfall event was calculated by using the total runoff amount during an entire rainfall event period and plot area. An event SLR $\left(\mathrm{t} \mathrm{km}^{-2}\right.$ event $\left.^{-1}\right)$ was obtained by using soil loss amount and plot area. Annual $\mathrm{H}(\mathrm{AH})$ and the annual SLR of each plot were obtained by summing the event-derived ones.

Table 1. Description of the selected runoff plots.

\begin{tabular}{ccccccccc}
\hline No. & $\begin{array}{c}\text { Gradient } \\
(\mathbf{\%})\end{array}$ & $\begin{array}{c}\text { Length } \\
(\mathbf{m})\end{array}$ & $\begin{array}{c}\text { Width } \\
\mathbf{( m )}\end{array}$ & $\begin{array}{c}\text { Area } \\
\left(\mathbf{m}^{\mathbf{2}} \mathbf{)}\right.\end{array}$ & Aspect & Type & Crop & Measure \\
\hline 1 & 29.6 & 10 & 5 & 50 & Sunny & Cultivated & Corn & - \\
2 & 25.7 & 10 & 5 & 50 & Northwestern & Cultivated & Corn & Contour tillage \\
3 & 6.1 & 10 & 5 & 50 & Sunny & Cultivated & Corn & Terrace $(4-m$ wide) \\
4 & 6.1 & 10 & 5 & 50 & Sunny & Cultivated & Corn & Contour tillage \\
5 & 11.0 & 10 & 5 & 50 & Sunny & Cultivated & Corn & Contour tillage \\
\hline
\end{tabular}

A self-recording rain gauge and rain barrel were installed near the plots to monitor rainfall process and rainfall amount. According to the records, rainfall duration (RD), rainfall amount $(\mathrm{P})$, mean rainfall intensity $\left(\mathrm{I}_{\mathrm{m}}\right)$, and maximum intensities at $30 \mathrm{~min}\left(\mathrm{I}_{30}\right)$ and $60 \mathrm{~min}\left(\mathrm{I}_{60}\right)$ were obtained. Annual rainfall amount $(\mathrm{AP})$ was obtained by summing event $P$.

Soils from the runoff plots were collected, and the soil texture and soil organic matter in Table 2 were obtained by Wang et al. [19]. The soil samples for moisture measurements before a rainfall event were taken from $0-10 \mathrm{~cm}$ and $10-20 \mathrm{~cm}$ depths using drilled soil cores. Sampling time intervals depended on the occurrence frequency of rainfall events. All the samples were transported to the laboratory, oven-dried, and weighed to determine their soil moistures.

Table 2. Soil properties of the runoff plots in the study area.

\begin{tabular}{ccccccc}
\hline \multirow{2}{*}{ Eigenvalue } & \multirow{2}{*}{ SOM (\%) } & \multicolumn{5}{c}{ Texture (Chinese Classification System) } \\
\cline { 3 - 7 } & & $\mathbf{> 0 . 0 5}$ & $\mathbf{0 . 0 5 - 0 . 0 1}$ & $\mathbf{0 . 0 1 - 0 . 0 0 5}$ & $\mathbf{0 . 0 0 5 - 0 . 0 0 1}$ & $<\mathbf{0 . 0 0 1}$ \\
\hline Mean & 1.57 & 60.9 & 15.00 & 3.22 & 6.00 & 14.88 \\
St.D & 0.69 & 12.58 & 4.36 & 1.53 & 1.00 & 2.55 \\
\hline
\end{tabular}

\subsection{Data Treatment and Statistical Analysis}

In order to study the effect of rainfall characteristics on surface runoff and soil loss, the K-means clustering method was used to group the erosive rainfall events in 2011-2019. To determine the number of groups, many criteria were used. Normally, the classification must meet the ANOVA criterion of significance $(p<0.05)$. In the present study, rainfall eigenvalues of $P, R D, I_{m}, I_{30}$, and $I_{60}$ were employed to group the erosive rainfall events.

In the present study, erosive rainfall was defined as the rainfall that induces runoff and soil loss. The mean annual runoff reduction efficiency (ARRE) of a soil conservation measure was calculated as follows:

$$
\text { ARRE }=\frac{\mathrm{AH}_{0}-\mathrm{AH}_{i}}{\mathrm{AH}_{0}}(i=2,3,4 \text {, or } 5)
$$

where $\mathrm{AH}_{0}$ represents the mean annual $\mathrm{H}$ on plot 1 (no soil conservation measures), and $\mathrm{AH}_{i}$ represents the mean annual $\mathrm{H}$ on the $i$ th plot (where a soil conservation measure is present). Therefore, separate ARRE for each plot were obtained. In order to evaluate the effects of contour tillage and terracing on surface runoff, their ARREs were not averaged in the present study. Similarly, the mean annual soil loss reduction efficiency (ASLRE) for each plot was calculated as follows:

$$
\text { ASLRE }=\frac{\mathrm{ASLR}_{0}-\mathrm{ASLR}_{i}}{\mathrm{ASLR}_{0}}(i=2,3,4, \text { or } 5)
$$


where $\mathrm{ASLR}_{0}$ represents the mean annual SLR on plot 1 , and $\mathrm{ASLR}_{i}$ represents the mean annual SLR on the $i$ th plot where a soil conservation measure is present. The calculated ASLREs were given the same treatment as the ARREs.

Pearson correlation analysis was performed to assess the relationships between $\mathrm{H}$, SLR, and their influencing factors. Fisher's protected least significant difference (LSD) test was conducted to compare the means of Hs and SLRs on the plots. Treatments were considered significant if $p<0.05$.

\section{Results}

\subsection{Rainfall Characteristics}

In 2011-2019, the mean AP was $507 \mathrm{~mm}$, ranging from 410 to $579 \mathrm{~mm}$. In contrast, the mean annual erosive rainfall amount was $326 \mathrm{~mm}$, ranging from 249 to $434 \mathrm{~mm}$. There were 85 erosive rainfall events in the study period, ranging from seven to eleven rainfall events per year (Figure 2a). Most erosive rainfalls occurred in July and August (Figure 2b).
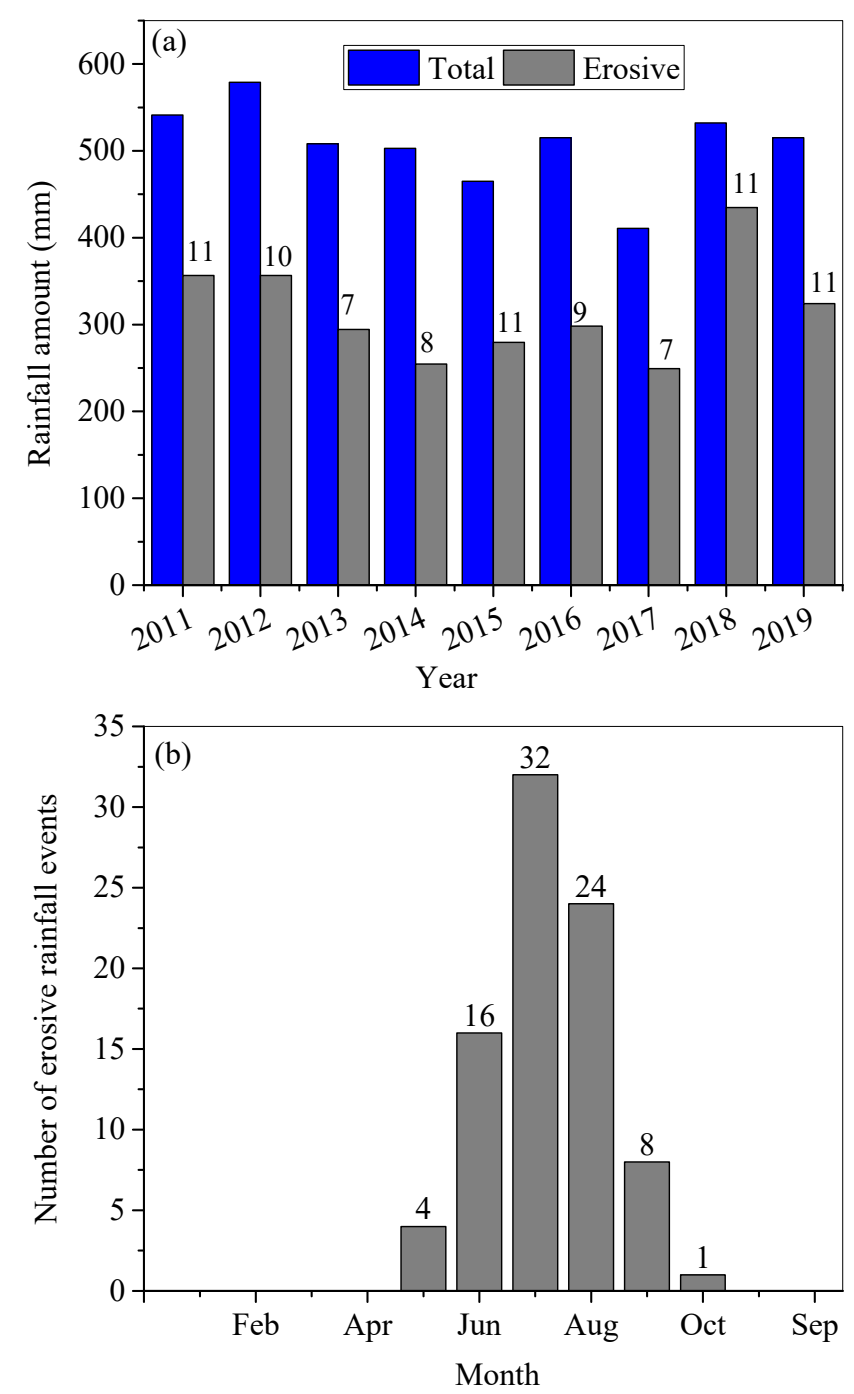

Figure 2. Annual total amount of rainfall and erosive rainfall between 2011-2019 (a). The number of erosive rainfall events in each month of the study period (b). The numbers on the erosive rainfall amount bars indicate the number of erosive rainfall events.

In comparison to $\mathrm{I}_{30}$ and $\mathrm{I}_{60}$, the $\mathrm{I}_{\mathrm{m}}$ had the largest mean square value (i.e., 854.79; Table 3), resulting from the largest coefficient of variation (CV) for the 85 erosive rainfall events (Table 4). The separate eigenvalues of $R D, P$, and $I_{m}$ were the significant rainfall 
eigenvalues used to group the 85 erosive rainfall events into three rainfall regimes (Table 3). Rainfall regime A occurred 62 times, accounting for $72.9 \%$ of the total. Rainfall regime B occurred 20 times, with an occurrence frequency that accounted for $23.5 \%$ of the total. Rainfall regime $\mathrm{C}$ had three rainfall events (Table 4). In accordance with the occurrence frequency, regime $\mathrm{A}$ had the shortest average $\mathrm{RD}$ of $176 \mathrm{~min}$, the lowest average $\mathrm{P}$ of $26 \mathrm{~mm}$, and the highest average $\mathrm{I}_{\mathrm{m}}$ of $14.18 \mathrm{~mm} \mathrm{~h}^{-1}$. Inversely, rainfall regime $C$ had the longest average $R D$, the highest average $P$, and the smallest average $I_{m}$ of $3.30 \mathrm{~mm} \mathrm{~h}^{-1}$. These three rainfall regimes had comparable $\mathrm{I}_{30}$ and $\mathrm{I}_{60}$ values, without significant differences at the 0.05 level, due to their smaller CVs (Table 4). The CV varied from 0.10 to 1.31 for the five eigenvalues. The short $\mathrm{RD}$, low $\mathrm{P}$, and high $\mathrm{I}_{\mathrm{m}}$ rainfall regime $\mathrm{A}$ had higher $\mathrm{CV}$ values for the three eigenvalues $\mathrm{P}, \mathrm{RD}$, and $\mathrm{I}_{\mathrm{m}}$ than the other two rainfall regimes. With respect to the 85 erosive rainfall events, the average $\mathrm{P}, \mathrm{I}_{\mathrm{m}}, \mathrm{I}_{30}$, and $\mathrm{I}_{60}$ values were $33.51 \mathrm{~mm}$, $11.45 \mathrm{~mm} \mathrm{~h}^{-1}, 28.73 \mathrm{~mm} \mathrm{~h}^{-1}$, and $20.77 \mathrm{~mm} \mathrm{~h}^{-1}$, respectively. The average RD of the 85 erosive rainfall events was $354.77 \mathrm{~min}$, ranging from 20 to $1940 \mathrm{~min}$ (Table 4).

Table 3. One-way analysis of variance (ANOVA) results using a K-means clustering classification method.

\begin{tabular}{|c|c|c|c|c|c|c|}
\hline \multirow{2}{*}{ Variables } & \multicolumn{2}{|c|}{ Cluster } & \multicolumn{2}{|c|}{ Error } & \multirow{2}{*}{$\mathbf{F}$} & \multirow{2}{*}{ Sig } \\
\hline & Mean Square & df & Mean Square & df & & \\
\hline RD & $4,980,828.25$ & 2 & $23,349.50$ & 82 & 213.32 & 0.00 \\
\hline $\mathrm{P}$ & 9573.87 & 2 & 434.34 & 82 & 22.04 & 0.00 \\
\hline $\mathrm{I}_{\mathrm{m}}$ & 854.79 & 2 & 121.57 & 82 & 7.03 & 0.00 \\
\hline $\mathrm{I}_{30}$ & 270.12 & 2 & 222.84 & 82 & 1.21 & 0.30 \\
\hline $\mathrm{I}_{60}$ & 59.44 & 2 & 162.97 & 82 & 0.37 & 0.70 \\
\hline
\end{tabular}

Table 4. Statistical features of the erosive rainfall events separated into three groups based on the rainfall regimes between 2011-2019.

\begin{tabular}{|c|c|c|c|c|c|c|}
\hline $\begin{array}{l}\text { Rainfall } \\
\text { Regime }\end{array}$ & Eigenvalue & Mean & $\begin{array}{c}\text { Range } \\
\text { (Min-Max) }\end{array}$ & $\begin{array}{l}\text { Standard } \\
\text { Deviation }\end{array}$ & $\begin{array}{l}\text { Variation of } \\
\text { Coefficient }\end{array}$ & Number \\
\hline \multirow{5}{*}{$\mathrm{A}$} & $\mathrm{P}(\mathrm{mm})$ & 26.01 & $4.80-105.20$ & 16.52 & 0.64 & 62 \\
\hline & $\mathrm{RD}(\mathrm{min})$ & 176.03 & $20.00-498.00$ & 138.04 & 0.78 & \\
\hline & $\mathrm{I}_{\mathrm{m}}(\mathrm{mm} \mathrm{min}-1)$ & 14.18 & $2.07-69.6$ & 12.68 & 0.89 & \\
\hline & $\mathrm{I}_{30}\left(\mathrm{~mm} \mathrm{~min}^{-1}\right)$ & 29.70 & $6.00-75.80$ & 15.85 & 0.53 & \\
\hline & $\mathrm{I}_{60}\left(\mathrm{~mm} \mathrm{~min}^{-1}\right)$ & 21.17 & $3.60-69.60$ & 12.76 & 0.60 & \\
\hline \multirow{5}{*}{$\mathrm{B}$} & $\mathrm{P}(\mathrm{mm})$ & 47.32 & $10.60-123.60$ & 31.21 & 0.66 & 20 \\
\hline & $\mathrm{RD}(\mathrm{min})$ & 705.30 & $500.00-1060.00$ & 188.27 & 0.27 & \\
\hline & $\mathrm{I}_{\mathrm{m}}\left(\mathrm{mm} \mathrm{min}^{-1}\right)$ & 4.20 & $1.03-11.36$ & 2.84 & 0.68 & \\
\hline & $\mathrm{I}_{30}\left(\mathrm{~mm} \mathrm{~min}^{-1}\right)$ & 23.90 & $6.40-37.40$ & 10.29 & 0.43 & \\
\hline & $\mathrm{I}_{60}\left(\mathrm{~mm} \mathrm{~min}^{-1}\right)$ & 18.74 & $4.50-57.20$ & 12.44 & 0.66 & \\
\hline \multirow{5}{*}{$\mathrm{C}$} & $\mathrm{P}(\mathrm{mm})$ & 96.37 & $82.50-108.10$ & 12.93 & 0.13 & 3 \\
\hline & RD (min) & 1711.67 & $1580.00-1940.00$ & 198.52 & 0.12 & \\
\hline & $\mathrm{I}_{\mathrm{m}}\left(\mathrm{mm} \mathrm{min}^{-1}\right)$ & 3.30 & $3.07-3.74$ & 0.34 & 0.10 & \\
\hline & $\mathrm{I}_{30}\left(\mathrm{~mm} \mathrm{~min}^{-1}\right)$ & 31.6 & $15.20-56.00$ & 21.54 & 0.68 & \\
\hline & $\mathrm{I}_{60}\left(\mathrm{~mm} \mathrm{~min}^{-1}\right)$ & 23.77 & $14.40-42.00$ & 15.79 & 0.66 & \\
\hline \multirow{5}{*}{ Total } & $\mathrm{P}(\mathrm{mm})$ & 33.51 & $4.80-123.60$ & 25.53 & 0.76 & 85 \\
\hline & $\mathrm{RD}(\mathrm{min})$ & 354.76 & $20.00-1940.00$ & 376.01 & 1.06 & \\
\hline & $\mathrm{I}_{\mathrm{m}}\left(\mathrm{mm} \mathrm{min}^{-1}\right)$ & 11.45 & $1.03-69.60$ & 14.98 & 1.31 & \\
\hline & $\mathrm{I}_{30}\left(\mathrm{~mm} \mathrm{~min}^{-1}\right)$ & 28.40 & $6.00-75.80$ & 14.95 & 0.53 & \\
\hline & $\mathrm{I}_{60}\left(\mathrm{~mm} \mathrm{~min}^{-1}\right)$ & 20.69 & $3.60-69.60$ & 12.67 & 0.61 & \\
\hline
\end{tabular}




\subsection{Surface Runoff}

During the study period, the mean AH differed greatly. Plot 1 without soil conservation measures had the highest $\mathrm{AH}$ ranging from 28.41 to $103.51 \mathrm{~mm}$ with an average of $71.30 \mathrm{~mm}$. This value was larger than that of the contour tillage plot 2 which had a comparable slope gradient to plot 1 . For the contour tillage plots 2,4 , and 5 , the annual SLR increased with an increasing slope gradient. The AH on plot 2 ranged from 32.28 to $98.30 \mathrm{~mm}$ with an average of $63.07 \mathrm{~mm}$, and the mean AH on plots 5 and 4 were $62.74 \mathrm{~mm}$ and $61.95 \mathrm{~mm}$, respectively. The terraced plot 3 with a slope gradient of $6.1 \%$ yielded the least number of runoff events (i.e., 9; Figure $3 \mathrm{~b}$ ) and the lowest $\mathrm{AH}$ ranging from 0 to $11 \mathrm{~mm}$ with an average of $2.86 \mathrm{~mm}$, which was significantly different from the results from the other plots at the 0.05 level (Figure 3a). For the five plots, event $\mathrm{H}$ was positively correlated with RD, $\mathrm{P}, \mathrm{I}_{30}$, and $\mathrm{I}_{60}$ at the 0.01 or 0.05 levels (Table 5). However, $\mathrm{H}$ was not significantly correlated with $\mathrm{I}_{\mathrm{m}}$ and antecedent soil moisture content (ASMC), although $\mathrm{I}_{\mathrm{m}}$ was an efficient indicator for grouping the rainfall events (Table 3 ).

In comparison to the $\mathrm{AH}$ on plot 1 without soil conservation measures, $96.03 \%$ of surface runoff was reduced for plot 3. However, lesser runoff was intercepted by the contour tillage plots 2, 4, and 5, with ARREs of $11.52 \%, 13.11 \%$, and $12.05 \%$, respectively (Figure 4).

The number of runoff-soil loss events differed among the plots. On plot 1, 77 events occurred. Impacted by the soil conservation measures and slope gradient, 71, 67, 63, and 9 events occurred on plots 2, 5, 4, and 3, respectively. For each plot, more runoff-soil loss events were caused by rainfall regime $\mathrm{A}$, followed by regimes B and C (Figure $3 \mathrm{~b}$ ). The average $\mathrm{Hs}$ of the 85 erosive rainfall events presented the same sequence (Figure 3c). Plot 1 yielded the highest $\mathrm{H}$, and plot 3 yielded the lowest one. Rainfall regimes affected $\mathrm{H}$ on each plot. Under rainfall regime A, the Hs increased from $0.2 \mathrm{~mm}$ on plot $3,6.19 \mathrm{~mm}$ on plot $4,6.29 \mathrm{~mm}$ on plot $5,6.35 \mathrm{~mm}$ on plot 2 , to $7.03 \mathrm{~mm}$ on plot 1 . Under rainfall regime $B$, the Hs increased from $0.23 \mathrm{~mm}$ on plot $3,6.23 \mathrm{~mm}$ on plot $4,6.44 \mathrm{~mm}$ on plot $5,6.66 \mathrm{~mm}$ on plot 2, to $8.09 \mathrm{~mm}$ on plot 1 . However, under rainfall regime $C$, plot 4 had the highest $\mathrm{H}$ of $16.4 \mathrm{~mm}$ and plot $3 \mathrm{had}$ the lowest one of $2.94 \mathrm{~mm}$. For each plot, rainfall regimes B and $\mathrm{C}$ had a higher $\mathrm{H}$, and rainfall regime $\mathrm{A}$ had a lower $\mathrm{H}$. For example, on plot 1 , the $\mathrm{Hs}$ were $7.03 \mathrm{~mm}, 8.09 \mathrm{~mm}$, and $14.42 \mathrm{~mm}$ under rainfall regimes A, B, and C, respectively. The average Hs on plots $1,2,4$, and 5 under each rainfall regime were significantly higher than that on plot 3 at the 0.05 level (Figure 3c).

\subsection{Soil Loss}

Soil losses from the plots had almost the same changing patterns as their corresponding $\mathrm{H}$ levels at both the annual and event scales. The steepest plot 1 without soil conservation measures had the largest annual SLRs of $2838.11 \mathrm{t} \mathrm{km}^{-2}$. For the three contour tillage plots 2,5 , and 4 , the mean annual SLRs increased with increasing slope gradient, ranging from $160.60 \mathrm{t} \mathrm{km}^{-2}$ on plot $4,455.94 \mathrm{t} \mathrm{km}^{-2}$ on plot 5 , to $2033.83 \mathrm{t} \mathrm{km}^{-2}$ on plot 2 . The terraced plot 3 had the lowest mean annual SLR of $3.49 \mathrm{t} \mathrm{km}^{-2}$ on plot 3 (Figure $5 \mathrm{a}$ ). Impacted by the implemented soil conservation measures and slope gradient, the mean annual SLRs on plots 1 and 2 were significantly different to those of the other plots at the 0.05 level. Similarly, the mean event SLRs increased from zero on plot 3, 7.00 on plot 4, 47.22 on plot $5,215.35$ on plot 2, to $300.51 \mathrm{t} \mathrm{km}^{-2}$ on plot 1 . Similar to surface runoff, soil loss was also significantly correlated with $\mathrm{P}, \mathrm{I}_{30}$, and $\mathrm{I}_{60}$, and was insignificantly correlated with $\mathrm{RD}, \mathrm{I}_{\mathrm{m}}$, and ASMC. In contrast to the mean annual SLR for plot 1, plot 3 had the highest ASLRE of $99.88 \%$, and plots 4 and 5 also had a higher ASLRE with values of $94.34 \%$ and $84.29 \%$, respectively. However, the ASLRE of plot 2 was only $28.34 \%$.

In contrast, the mean event SLR under rainfall regime A was insignificantly higher than that of rainfall regime B for the individual plots (Figure $5 b$ ). However, the mean event SLR under regime $C$ was higher than that of regimes $A$ and $B$ at the 0.05 level on each plot. For example, the SLRs on plot 1 were $319.54 \mathrm{t} \mathrm{km}^{-2}, 225.39 \mathrm{t} \mathrm{km}^{-2}$, and $408.00 \mathrm{t} \mathrm{km}^{-2}$ under rainfall regimes $\mathrm{A}, \mathrm{B}$, and $\mathrm{C}$, respectively. 

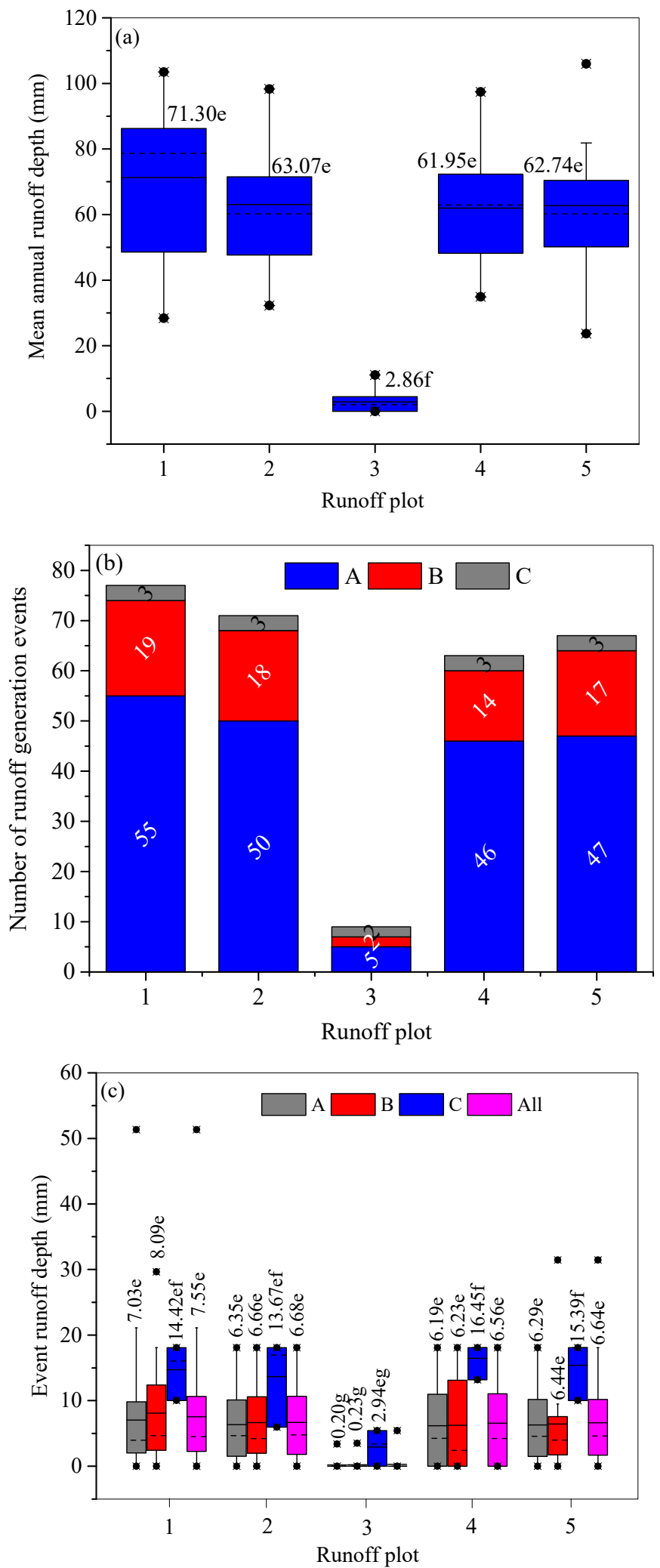

Figure 3. Mean annual runoff depth and standard deviation (a); number of runoff generation events induced by rainfall regimes $\mathrm{A}, \mathrm{B}$, and $\mathrm{C}$ on the five plots (b); and mean event runoff depth and standard deviation under each rainfall regime (c). Note: Values on the columns with the same letter in $(\mathbf{a}, \mathbf{c})$ were not significantly different at the 0.05 level. The solid line in the box represents the mean value, and the dotted line represents the median value. 
Table 5. Pearson correlation coefficients between runoff, soil loss rate, and their influencing factors for the five runoff plots.

\begin{tabular}{|c|c|c|c|c|c|c|c|}
\hline Runoff Plot & Eigenvalue & RD & $\mathbf{P}$ & $\mathbf{I}_{\mathrm{m}}$ & $\mathbf{I}_{30}$ & $I_{60}$ & ASMC \\
\hline \multirow{2}{*}{1} & $\mathrm{H}$ & 0.224 * & $0.607^{* *}$ & 0.098 & $0.528 * *$ & $0.487^{* *}$ & -0.050 \\
\hline & SLR & -0.019 & $0.304 * *$ & $0.280 * *$ & $0.448 * *$ & $0.416 * *$ & 0.011 \\
\hline \multirow[b]{2}{*}{2} & $\mathrm{H}$ & 0.235 * & $0.518 * *$ & 0.180 & $0.586 * *$ & $0.486 * *$ & -0.060 \\
\hline & SLR & 0.132 & 0.349 ** & 0.186 & $0.404^{* *}$ & $0.381 * *$ & -0.096 \\
\hline \multirow{2}{*}{3} & $\mathrm{H}$ & $0.402 * *$ & $0.521 * *$ & 0.024 & $0.286^{* *}$ & $0.284^{* *}$ & 0.002 \\
\hline & SLR & -0.004 & $0.282 * *$ & 0.127 & 0.245 * & $0.320 * *$ & 0.049 \\
\hline \multirow{2}{*}{4} & $\mathrm{H}$ & $0.316^{* *}$ & $0.581 * *$ & 0.061 & $0.514^{* *}$ & $0.441^{* *}$ & 0.003 \\
\hline & SLR & -0.100 & $0.219 *$ & 0.181 & $0.281^{* *}$ & $0.287^{* *}$ & 0.112 \\
\hline \multirow{2}{*}{5} & $\mathrm{H}$ & $0.220 *$ & $0.521 * *$ & 0.182 & $0.542 * *$ & $0.491^{* *}$ & 0.006 \\
\hline & SLR & $0.315^{* *}$ & $0.426^{* *}$ & 0.070 & $0.321^{* *}$ & $0.345^{* *}$ & 0.134 \\
\hline
\end{tabular}

Note: SLR: soil loss rate; ASMC: antecedent soil moisture content. ${ }^{*}$ represents significance at the 0.05 level and ${ }^{* *}$ represents significance at the 0.01 level.

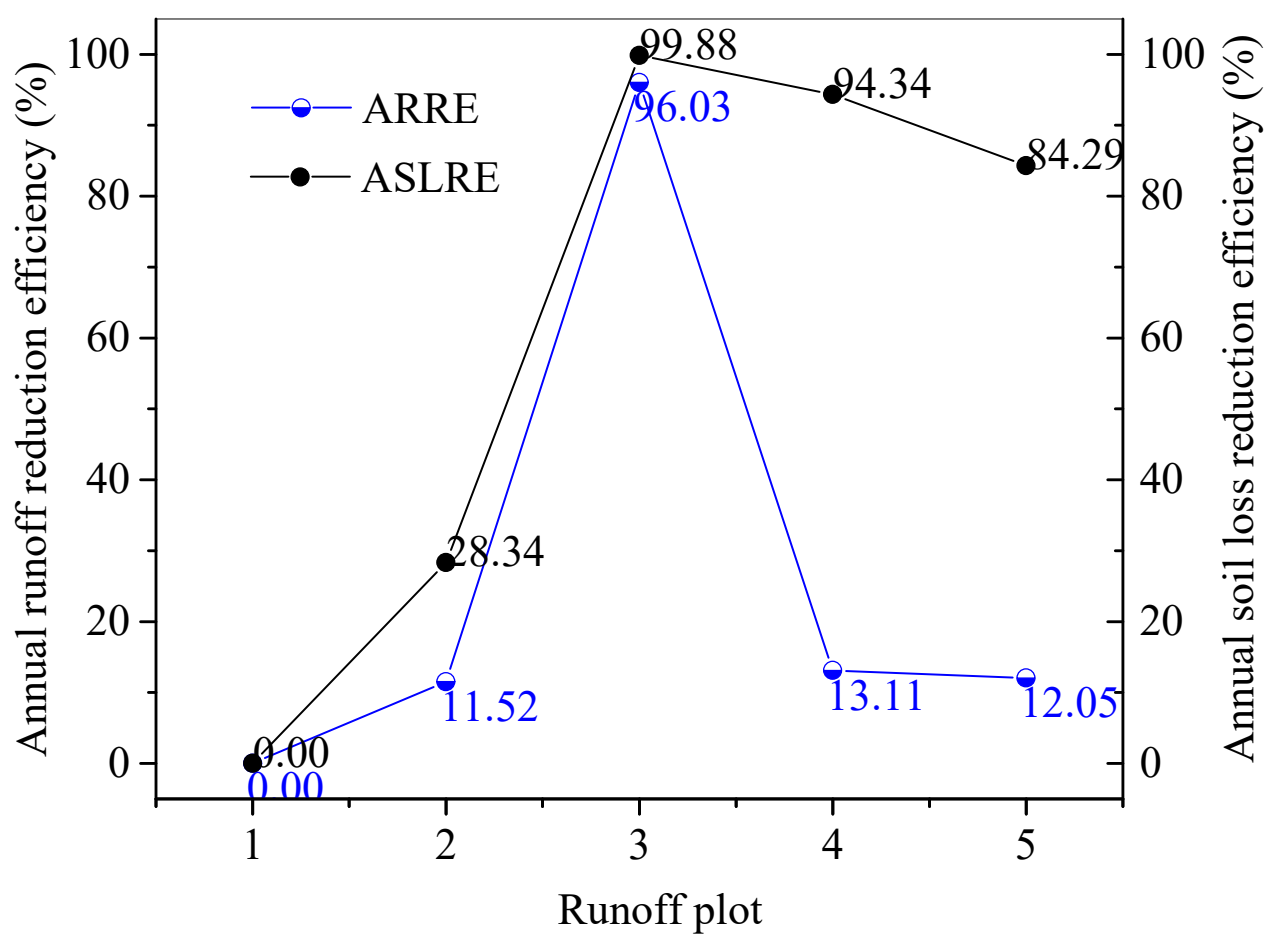

Figure 4. Annual runoff reduction efficiency and annual soil loss reduction efficiency of the soil conservation measures on the selected plots.

\subsection{Runoff-Soil Loss Relationship}

Runoff and soil loss relationships for each plot under different rainfall regimes are shown in Figure 6. The scattered points were fitted with linear regressions. The slope $b$ of the linear regression function $y=a+b x$ reflects the sensitivity of the soil to erosion. Similarly, impacted by soil conservation measures and the slope gradient, the changing pattern of the $b$ values agreed with those of the mean annual AH and SLR. For all the erosive rainfall events, the $b$ value on plot 1 was the highest at 35.39 , followed by values of 30.82 on plot 2, 9.04 on plot 5, and 1.94 on plot 4 . However, there was no apparent relationship between runoff and soil loss on plot 3 . For individual runoff plots, the $b$ values were usually less under rainfall regime $A$, and higher under rainfall regimes $B$ and $C$. For example, for plot 1 , the $b$ value was 25.16 under rainfall regime $A$, however the $b$ values were 38.14 and 28.04 under regimes B and C, respectively. 

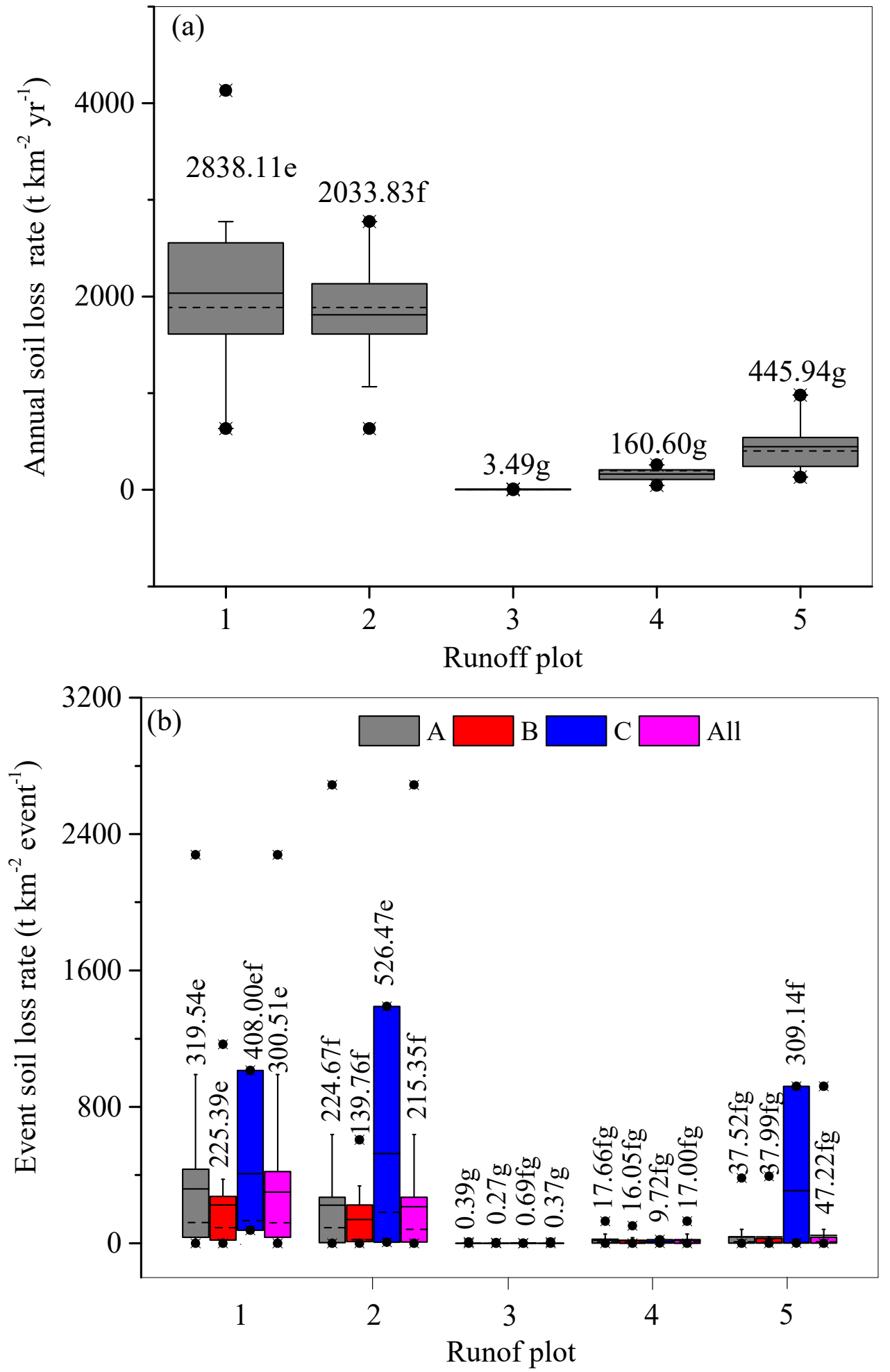

Figure 5. Annual soil loss rate (a) and event soil loss rate (b) for the 85 rainfall events under each rainfall regime. Note: Average values on the columns with the same letter are not significantly different at the 0.05 level. The solid line in the box represents the mean value, and the dotted line represents the median value. 

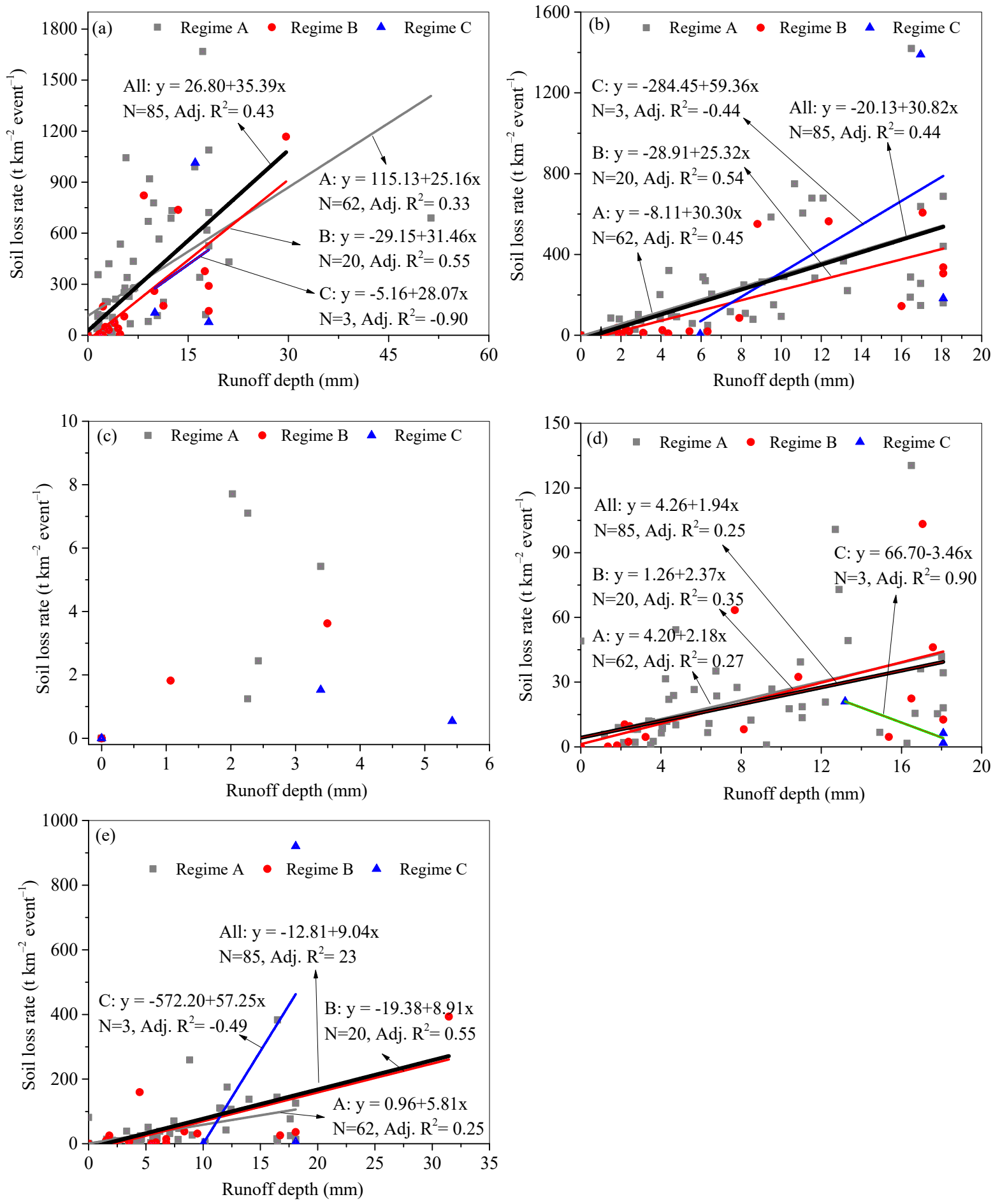

Figure 6. Relationships between the event runoff depth and event soil loss rate under different rainfall regimes for plot 1 (a), plot 2 (b), plot 3 (c), plot 4 (d), and plot 5 (e).

\section{Discussion}

\subsection{Effect of Antecedent Soil Moisture and Soil Crust}

Soil moisture is an important factor in influencing surface runoff and soil loss, and higher ASMCs usually induce more runoff and soil loss [28]. However, there were no significant correlations between the ASMC, H, and SLR in the present study (Table 5). This could result from the interactions of the soil crust and rills as affected by ASMC and the runoff generation type in the study area. Under the impact of rainfall, an encrusted 
soil surface can greatly reduce the infiltration rate [29-31]. The presence of crust only 0.1 $\mathrm{mm}$ thick may reduce the infiltration rate from $800 \mathrm{~cm} \mathrm{day}^{-1}$ to $70 \mathrm{~cm} \mathrm{day}^{-1}$ [32]. Qinna and Awwad [33] found that the permeability of deep soils was up to 2000-fold higher than that of the surface soil crust. However, when rainfall intensity is high enough, the encrusted soil can be destroyed and rills and/or even ephemeral gullies develop that can increase the infiltration rate [34-36]. Soil crust is easily formed on the gentle slopes which increases surface runoff, and faster runoff velocity on steep slopes also increases surface runoff. This can explain the comparable ARREs for the gentle plots 4 and 5 and the steep plots 1 and 2. However, terracing can reduce runoff velocity and increase higher runoff infiltration, resulting in a higher ARRE for the terraced plot 3. In comparison to plots 4 and 5 , less runoff generation events occurred on terraced plot 3 . In respect of sediment loss control, the contour tillage on plots 4 and 5 can greatly filter sediment although it allows more runoff to run downslope. As a result, the ASLREs of plots 4 and 5 were just slightly lower than that of terraced plot 3. Further comparison indicated that the event SLRs from plot 5 ranged from 0-920 $\mathrm{t} \mathrm{km}^{-2}$ event $^{-1}$, whereas most of the events had an SLR of less than $100 \mathrm{t} \mathrm{km}^{-2}$ event $^{-1}$. The event SLR on plot 4 ranged from 0 to $102 \mathrm{t} \mathrm{km}^{-2}$ event $^{-1}$. Therefore, the ASLREs of plots 4 and 5 were also comparable.

Soils with a higher ASMC can accelerate the formation and destructive processes of soil crust [36], resulting in its complex effect on $\mathrm{H}$ and soil loss. Field investigations demonstrated that sometimes rills develop on the lower section of the plots after a high intensity rainfall event. These changes of soil crust and rills with rainfall duration make the relationship between ASMC and runoff complex [35]. The special runoff generation type in this region discussed below could also induce insignificant correlations of ASMC and $\mathrm{H}$. Under short RD and high rainfall intensity conditions, the infiltration of excess runoff dominates, resulting in a lower $\mathrm{H}$. However, longer RD rainfall and higher P events yielded a higher $\mathrm{H}$ (Figure $3 \mathrm{~b}$ ), due to the dominant saturation of excess runoff. Affected by the complex interactions of soil crust and the development of rills, and the changes in the runoff generation type with time duration, the ASMC did not significantly affect the $\mathrm{H}$ and SLR on the plots in the study area.

\subsection{Effect of Rainfall Regimes}

In the present study, $\mathrm{H}$ and SLR were not significantly correlated with $\mathrm{I}_{\mathrm{m}}$, although it was an efficient indicator to group the rainfall events (Table 3), implying that $\mathrm{I}_{30}$ and $I_{60}$ were more efficient than $I_{m}$ in influencing runoff and soil loss [35-38]. In the study area, rainfall regime $\mathrm{A}$ is the most frequently occurring rainfall event, with a short $\mathrm{RD}$, low $\mathrm{P}$, and high $\mathrm{I}_{\mathrm{m}}$. This type of rainfall regime has been proved to produce more surface runoff and soil loss than regimes $B$ and $C[38,39]$. However, in the present study, rainfall regime $\mathrm{A}$ induced a lower $\mathrm{H}$ (Figure $3 \mathrm{c}$ ). In the earth-rocky hilly region, the infiltration of excess runoff dominates the early stage of a rainfall event. However, as the duration of the rainfall event increases, the runoff generation type turns from infiltration excess runoff into saturation excess runoff [40]. In contrast to the infiltration excess runoff on the Chinese Loess Plateau $[35,38,39]$, this kind of runoff generation type resulted in significantly positive correlations between $\mathrm{RD}$ and $\mathrm{H}$ (Table 5), inducing a higher $\mathrm{H}$ on the plots under rainfall regimes $B$ and $C$ (Figure $3 b$ ).

Consistent with previous studies [35,38,39], higher SLRs occurred under rainfall regime A (Figure $5 b$ ), resulting from its significantly higher $I_{m}$ (Table 4). As mentioned above, soil crust usually develops under raindrop impact [30,35]. However, the encrusted soil which is developed on coarsely textured soil (Table 2) can easily be destroyed when rainfall event of higher intensity occurs, and more loose soil underneath is the readily available for erosion, resulting in a higher sediment concentration and SLR [36,41]. This inference can be verified from the fitting lines of $\mathrm{H}$ versus SLR under different rainfall regimes (Figure 6). For example, according to the regression functions of the fitting lines for plot 1 under rainfall regimes $A$ and $B$, the average event $H$ of $7.03 \mathrm{~mm}$ under rainfall regime A produced an SLR of $292.00 \mathrm{t} \mathrm{km}^{-2}$ event $^{-1}$, which is larger than the SLR of 
$225.36 \mathrm{~m}^{-2}$ event $^{-1}$ derived from the average event $\mathrm{H}$ of $8.09 \mathrm{~mm}$ under rainfall regime B. Rainfall regime $\mathrm{C}$ had a similar $\mathrm{I}_{30}$ and $\mathrm{I}_{60}$ to rainfall regime $\mathrm{A}$, but with a much longer RD of $1171 \mathrm{~min}$ and a higher $\mathrm{P}$ of $96.37 \mathrm{~mm}$ (Table 4), resulting in the highest $\mathrm{H}$ and SLR (Figures $3 c$ and $5 b$ ). However, because rainfall regime $C$ consisted of only three rainfall events, the majority of the soil loss from plots was still induced by rainfall regime A.

\subsection{Effect of Slope Gradient}

Slope gradient is an important factor in influencing surface runoff and soil loss [42-44]. As the slope gradient increases, the runoff-holding capacity of soil conservation measure will decrease. Zhao et al. [44] found that the efficiency of soil loss reduction by contour tillage decreased by $3.08 \%$ with a gradient increment of one degree. In the RUSLE2 model, the effect of slope gradient is regarded as the greatest influencing factor before contour failure [45]. In the present study, plots 2, 4, and 5 had the same soil conservation measure (i.e., contour tillage). Affected by slope gradients (Table 1), the average event Hs on the plots increased with increasing slope gradient, although their differences were insignificantly at the 0.05 level (Figure $3 b$ ). However, the average event SLR on plot 2 was significantly higher than that of plots 4 and 5 (Figure $5 \mathrm{~b}$ ). This result is consistent with the published literatures [46,47]. Therefore, the ASLREs of contour tillage measures on plots $4(94.34 \%)$ and $5(84.29 \%)$ with gentle slopes were rather higher than on plot 2, although their ARREs differed little, ranging from $11.52 \%$ to $13.11 \%$ for the 85 rainfall events. It has also been confirmed that contour tillage has a greater sediment reduction effect than runoff reduction effect by Jia et al. [7] through a meta-analysis in China.

\subsection{Effect of Soil Conservation Measures}

Contour tillage and terracing are the two most implemented soil conservation measures across China and the world [7,48,49]. In the present study, the selected runoff plots are nearby with the same soil type and rainfall characteristics. The primary differences lie in the implemented soil conservation measures and slope gradients. In the present study, the terraced plot 3 had a higher ARRE and a lower number of runoff generation events than the plots with contour tillage. This result agrees with the reported conclusions [50-52]. However, terraced plots had a slightly lower ASLRE to the contour tillage plots 4 and 5 (Figure 6). This could result from the intense sediment filter function of contour tillage measures on gentle slopes. In comparison, its filter function became lower on steep slopes (e.g., plot 2). These comparisons imply that contour tillage is efficient to control soil loss but cannot efficiently intercept runoff on gentle slopes.

In recent years, the deterioration in water quality and a shortage of water in the Miyun Reservoir have threatened Beijing's drinking water supply [12,23], and thus "water saving" soil conservation measures should be promoted in this region [53]. In the present study, the terraced plot can effectively intercept both runoff and sediment that could greatly prevent runoff from entering into the Miyun Reservoir, affecting the amount of drinking water for Beijing. Furthermore, the construction of terracing is costly and it occupies a large part of a field. Therefore, terraces should be cautiously implemented in the study area. On gentle slopes, contour tillage should be promoted because it allows more runoff to route downstream whereas it can efficiently control soil loss.

\section{Conclusions}

In the present study, surface runoff and soil loss from five cultivated slopes were monitored in 2011-2019 in a hilly region of northern China, and 85 erosive rainfall events occurred during the study period. The 85 erosive rainfall events were grouped into three regimes based on K-means cluster classification method, and the effects of rainfall regimes and soil conservation measures (i.e., contour tillage and terracing) on runoff and soil loss of the cultivated plots were evaluated.

Responses of runoff and soil loss to the three rainfall regimes were different. The frequently occurring rainfall regime $\mathrm{A}$ had a short $\mathrm{RD}$, low $\mathrm{P}$, and high $\mathrm{I}_{\mathrm{m}}$, producing a 
higher SLR and lower $\mathrm{H}$. However, rainfall regime $\mathrm{B}$ with a higher RD, $\mathrm{P}$, and low $\mathrm{I}_{\mathrm{m}}$ yielded a higher $\mathrm{H}$ and lower SLR. Terraced plots can concurrently intercept runoff and sediment, resulting in the highest ARRE (i.e., 96.03\%) and ASLRE (i.e., 99.88\%) on gentle slopes. Although contour tillage measures had comparable ASLREs to terraced plot 3, their ARREs were much smaller than the terracing on gentle slopes. The effects of rainfall characteristics and soil conservation measures increased with decreasing slope gradients.

In the Miyun Reservoir catchment where water shortages exist, water-saving soil conservation measures should be given priority. Therefore, contour tillage should be promoted on gentle slopes, and terracing should be given further attention in both the study area and similar regions around the world, as it can intercept a large portion of surface runoff which could greatly reduce the downstream water quantity, which exacerbates water shortages and endanger the safety of drinking water in downstream areas.

Funding: This work was financially funded by the Beijing Natural Science Foundation (grant number 8202045) and the National Natural Science Foundation of China (grant number 41977066).

Institutional Review Board Statement: Not applicable.

Informed Consent Statement: Not applicable.

Data Availability Statement: The data presented in this study are available on request from the corresponding author.

Acknowledgments: Special thanks are owed to the two anonymous reviewers for their invaluable suggestions to the improvement of the manuscript.

Conflicts of Interest: The author declares no conflict of interest.

\section{References}

1. Damnati, B.; Ibrahimi, S.; Radakovitch, Q. Quantifying erosion using ${ }^{137} \mathrm{Cs}$ and ${ }^{210} \mathrm{~Pb}$ in cultivated soils in three Mediterranean watershed: Synthesis study from El Hachef, Raouz and Nakhla (North West Morocco). J. Afr. Earth Sci. 2013, 79, 50-57. [CrossRef]

2. Wuepper, D.; Borrelli, P.; Finger, R. Countries and the global rate of soil erosion. Nat. Sustain. 2020, 3, 51-55. [CrossRef]

3. Borrelli, P.; R4obinson, D.A.; Fleischer, L.R.; Lugato, E.; Ballabio, C.; Alewell, C.; Meusburger, K.; Modugno, S.; Schutt, B.; Ferro, V.; et al. An assessment of the global impact of 21st century land use change on soil erosion. Nat. Commun. 2017, 8, 1-13. [CrossRef] [PubMed]

4. Alatorre, L.C.; Beguería, S.; Lana-Renault, N.; Navas, A.; García-Ruiz, J.M. Soil erosion and sediment delivery in a mountain catchment under scenarios of land use change using a spatially distributed numerical model. Hydrol. Earth Sys. Sci. Dis. 2012, 16, 1321-1334. [CrossRef]

5. Didoné, E.J.; Minella, J.P.G.; Evrard, O. Measuring and modelling soil erosion and sediment yields in a large cultivated catchment under no-till of Southern Brazil. Soil Tillage Res. 2017, 174, 24-33. [CrossRef]

6. Aneseyee, A.B.; Elias, E.; Soromessa, T.; Feyisa, G.L. Land use/land cover change effect on soil erosion and sediment delivery in the Winike watershed, Omo Gibe Basin, Ethiopia. Sci. Total Environ. 2020, 728, 138776. [CrossRef] [PubMed]

7. Jia, L.Z.; Zhao, W.W.; Zhai, R.J.; An, Y.M.; Pereira, P. Quantifying the effects of contour tillage in controlling water erosion in China: A meta-analysis. Catena 2020, 195, 104829. [CrossRef]

8. $\quad$ Bai, L.C.; Wang, N.; Jiao, J.Y.; Chen, Y.X.; Tang, B.Z.; Wang, H.L.; Chen, Y.L.; Yan, X.Q.; Wang, Z.J. Soil erosion and sediment interception by check dams in a watershed for an extreme rainstorm on the Loess Plateau, China. Int. J. Sediment Res. 2020, 35, 408-416. [CrossRef]

9. Ge, F.L.; Zhang, J.H.; Su, Z.G.; Nie, X.J. Response of changes in soil nutrients to soil erosion on a purple soil of cultivated sloping land. Acta Ecol. Sin. 2007, 27, 459-464. [CrossRef]

10. He, Y.Y.; Wang, X.Y.; Duan, S.H. Characteristics of runoff and sediment during individual rainfall in upper area of Miyun Reservoir. Transac. Chin. Soc. Agric. Eng. 2015, 31, 134-141.

11. Han, L.F.; Gao, B.; Lu, J.; Zhou, Y.; Xu, D.Y.; Gao, L.; Sun, K. Pollution characteristics and source identification of trace metals in riparian soils of Miyun Reservoir, China. Ecotox. Environ. Saf. 2017, 144, 321-329. [CrossRef] [PubMed]

12. Qiu, J.L.; Shen, Z.Y.; Hou, X.S.; Xie, H.; Leng, G.Y. Evaluating the performance of conservation practices under climate change scenarios in the Miyun Reservoir Watershed, China. Ecol. Eng. 2020, 143, 105700. [CrossRef]

13. Qiu, J.L.; Shen, Z.Y.; Huang, M.Y.; Zhang, X.S. Exploring effective best management practices in the Miyun reservoir watershed, China. Ecol. Eng. 2018, 123, 30-42. [CrossRef]

14. Li, H.Y.; Di, Y.M.; Li, D.Q.; Liang, J.; Guo, X.Y. Spatial and temporal variations of water quality in a wetland-reclaimed water-supplied purification urban river: Case study in Chaobai River of Beijing. Res. Environ. Sci. 2007, 30, $1542-1552$. 
15. Wang, P.J.; Rene, E.R.; Yan, Y.L.; Ma, W.F.; Xiang, Y.Y. Spatiotemporal evolvement and factors influencing natural and synthetic EDCs and the microbial community at different groundwater depths in the Chaobai watershed: A long-term field study on a river receiving reclaimed water. J. Environ. Manag. 2019, 246, 647-657. [CrossRef] [PubMed]

16. Wang, S.F.; Wang, X.K.; Ouyang, Z.Y. Effects of land use, climate, topography and soil properties on regional soilorganic carbon and total nitrogen in the Upstream Watershed of Miyun Reservoir, North China. J. Environ. Sci. 2012, 24, 387-395. [CrossRef]

17. Xu, E.Q.; Zhang, H.Q. Relationship between land use and nutrients in surface runoff in upper catchment of Miyun Reservoir, China. J. Appl. Ecol. 2018, 29, 2869-2878.

18. Wei, J.; Zheng, X.G.; Wang, C.L.; Zhang, G.X.; Liu, J.T. Soil arsenic content and environmental quality assessment in the upstream basin of Guanting Reservoir and Miyun Reservoir. Environ. Chem. 2019, 38, 71-77.

19. Wang, X.Y.; Hu, Q.J.; Zhu, F.Y.; He, W. Loss of nutrients in runoff and soil in the watershed of Miyun Reservoir-as a example of Shixia experimental area. J. Cap. Norm. Univ. 2001, 22, 79-85.

20. Li, Z.J. Impacts of different allocation plans as soil and water conservation measures on annual runoff in the Chaohe River basin. Bull. Soil Water Conserv. 2010, 30, 108-112.

21. He, J.J.; Cai, Q.G.; Wang, X.Q. Research on paradigm of soil erosion comprehensive control about Shixia small watershed in the upstream of Miyun Reservoir. J. Nat. Resour. 2009, 24, 585-593.

22. Feng, J.J.; Shi, M.C.; Jiang, Q.E. Influence of land use/cover change on soil erosion in Chaobai River basin. Sci. Soil Water Conserv. 2019, 17, 121-132.

23. Yan, T.Z.; Bai, J.W.; Arsenio, T.; Shen, Z.Y. Future climate change impacts on streamflow and nitrogen exports based on CMIP5 projection in the Miyun Reservoir Basin, China. Ecohydrol. Hydrobiol. 2019, 19, 266-278. [CrossRef]

24. Cai, X.G. Benefits from soil and water conservation measures on reducing runoff and sediments in Shixia small watershed. Res. Sci. 2001, 2, 79-85.

25. Gao, Y. Study on the effect of different soil conservation measures on soil erosion in Shixia catchment. Eng. Technol. Res. 2018, 29, 255-256.

26. Pang, S.J.; Wang, X.Y.; Melching, C.S.; Feger, K.H. Development and testing of a modified SWAT model based on slope condition and precipitation intensity. J. Hydrol. 2020, 588, 125098. [CrossRef]

27. Xu, J.J.; Zhang, J.J.; Li, M.Y.; Wang, F.Z. Effect of rain peak morphology on runoff and sediment yield in Miyun water source reserve in China. Water 2019, 11, 2429. [CrossRef]

28. Meißl, G.; Zieher, T.; Geitner, C. Runoffresponse to rainfall events considering initial soil moisture-Analysis of 9-year records in a small Alpine catchment (Brixenbach valley, Tyrol, Austria. J. Hydrol. Reg. Stud. 2020, 30, 100711. [CrossRef]

29. Vandervaere, J.P.; Peugeot, C.; Angulo Jaramillo, R.; Vauclin, M.; Lebel, T. Estimating hydraulic conductivity of crusted soils by using disc infiltrometers and micro-tensiometers. J. Hydrol. 1997, 188, 203-223. [CrossRef]

30. Esteves, M.; Lapetite, J.M. A multi-scale approach of runoff generation in a Sahelian gully catchment: A case study in Niger. Catena 2003, 50, 255-271. [CrossRef]

31. Hardie, M.; Almajmaie, A. Measuring and estimating the hydrological properties of a soil crust. J. Hydrol. 2019, 574, 12-22. [CrossRef]

32. McIntyre, D.S. Permeability measurements of soil crusts by raindrop impact. Soil Sci. 1958, 85, 185-189. [CrossRef]

33. Qinna, M.I.A.; Awwad, A.M.A. Infiltration rate measurements in arid soils with surface crust. Irrig. Sci. 1998, 18, 83-89. [CrossRef]

34. Peugeot, C.; Esteves, M.; Rajot, J.L.; Vandervaere, J.P.; Galle, S. Runoff generation processes: Results and analysis of field data collected at the central supersite of the Hapex-Sahel experiment. J. Hydrol. 1997, 188, 179-202. [CrossRef]

35. Le Bissonnais, Y.; Renaux, B.; Delouche, H. Interactions between soil properties and moisture content in crust formation, runoff and interrill erosion from tilled loess soils. Catena 1995, 25, 33-46. [CrossRef]

36. Fang, H.Y.; Cai, Q.G.; Chen, H.; Li, Q.Y. Effect of rainfall regime and slope on runoff in a gullied loess region on the Loess Plateau in China. Environ. Manag. 2008, 42, 402-411. [CrossRef]

37. Fang, H.Y.; Sun, L.Y.; Tang, Z.H. Effects of rainfall and slope on runoff, soil erosion and rill development: An experimental study using two loess soils. Hydrol. Process. 2015, 29, 2649-2658. [CrossRef]

38. Wei, W.; Chen, L.D.; Fu, B.J.; Huang, Z.L.; Wu, D.P.; Gui, L.D. The effect of land uses and rainfall regimes on runoff and soil erosion in the semi-arid loess hilly area, China. J. Hydrol. 2007, 335, 247-258. [CrossRef]

39. Chen, H.; Zhang, X.P.; Alba, M.; Yan, R.; Ren, Q.F.; Ren, Z.Y.; Yang, Y.H.; Zhao, W.H.; Lin, P.F.; Liu, B.Y.; et al. Effects of vegetation and rainfall types on surface runoff and soil erosion on steep slopes on the Loess Plateau, China. Catena 2018, 170, 141-149. [CrossRef]

40. He, P.; Zhang, G.S.; Bian, R.Y. A study of runoff yield in mid-area of Haihe basin. Hydr. Sci. Technol. 2001, 22, 45-50.

41. Hu, Y.X.; Fister, W.; He, Y.; Kuhn, N.J. Assessment of crusting effects on interrill erosion by laser scanning. PeerJ 2019,8 , e8487. [CrossRef]

42. Guo, J.Z. Discussion on the issue of the relations of slope gradient and runoff amount and sediment production. Yel. Riv. 1958, 3, 47-49.

43. Fox, D.M.; Bryan, R.B.; Price, A.G. The influence of slope angle on final infiltration rate for interrill conditions. Geoderma 1997, 80, 181-194. [CrossRef]

44. Zhao, L.S.; Hou, R.; Wu, F.Q.; Dai, Q.H. Effect of slope gradient on soil and water conservation benefit of tillage practices in agriculture lands. J. Soil Water Conserv. 2017, 31, 69-78. 
45. Hessel, R.; Messing, I.; Liding, C.; Ritsema, C.; Stolte, J. Soil erosion simulations of land use scenarios for a small Loess Plateau catchment. Catena 2003, 54, 289-302. [CrossRef]

46. Zhao, L.; Liang, X.; Wu, F. Soil surface roughness change and its effect on runoff and erosion on the Loess Plateau of China. J. Arid Land 2014, 6, 400-409. [CrossRef]

47. Wu, Q.J.; Wang, L.H.; Wu, F.Q. Effects of structural and depositional crusts on soil erosion on the Loess Plateau of China. Arid Land Res. Manag. 2016, 30, 432-444. [CrossRef]

48. Chen, D.; Wei, W.; Chen, L.D. Effects of terracing practices on water erosion control in China: A meta-analysis. Earth Sci. Rev. 2017, 173, 109-121. [CrossRef]

49. Xin, Y.; Liu, G.; Xie, Y.; Gao, Y.; Liu, B.Y.; Shen, B. Effects of soil conservation practices on soil losses from slope farmland in northeastern China using runoff plot data. Catena 2019, 174, 417-424. [CrossRef]

50. Zhao, J.L.; Yang, Z.Q.; Gover, G. Soil and water conservation measures reduce soil and water losses in China but not down to background levels: Evidence from erosion plot data. Geoderma 2019, 337, 729-741. [CrossRef]

51. Chen, J.; Xiao, H.B.; Li, Z.W.; Liu, C.; Tang, C.J. How effective are soil and water conservation measures (SWCMs) in reducing soil and water losses in the red soil hilly region of China? A meta-analysis of field plot data. Sci. Total Environ. 2020, 735, 139517. [CrossRef] [PubMed]

52. Fernandes, A.C.S.A.; Gontijo, L.M. Terracing field slopes can concurrently mitigate soil erosion and promote sustainable pest management. J. Environ. Manag. 2020, 269, 110801. [CrossRef] [PubMed]

53. Li, X.B.; Ma, Z.Z.; Yao, X.Y.; Jing, K.; Zhu, H.Y. Current status and comprehensive control strategies of soil erosion for rocky mountain areas in the Northern China. Sci. Soil Water Conserv. 2008, 6, 9-15. 